Volume 6 No. 2, Desember 2019

P-ISSN: 2406-808X // E-ISSN: 2550-0686

https://journal.iainlangsa.ac.id/index.php/ikhtibar

https://doi.org/10.32505/ikhtibar.v6i2.605

\title{
PESANTREN DAN KITAB KUNING
}

\author{
Indra Syah Putra ${ }^{1}$ dan Diyan Yusr ${ }^{2}$ \\ STAI JM Tanjung Pura \\ riyusyandi@gmail.com
}

\begin{abstract}
Abstrak
Kitab kuning merupakan kitab yang dijadikan sumber belajar di pesantren dan lembaga pendidikan tradisional. Dalam tradisi pesantren, kitab kuning merupakan ciri dan identitas yang tidak dapat dilepaskan. Sebagai lembaga kajian dan pengembangan ilmu-ilmu keislaman, pesantren menjadikan kitab kuning sebagai identitas yang inheren dengan pesantren Abudin Nata menambahkan bahwa kita kuning merupakan hasil karya tulis Arab yang disusun oleh para sarjana muslim abad pertengahan, sekitar abad 16-18. Ciri umum kitab kuning sebagai berikut: al-kitab yang ditulis bertulisan Arab, (2)umumnya ditulis tanpa baris, bahkan tanpa tanda baca dan koma, (3)berisikan ilmu keislaman, (4)metode penulisannya dinilai kuno, (5)dicetak di atas kertas yang berwarna kuning, (6)lazimnya dipelajari di pondok pesantren. Keberadaan kitab kuning ini menjadi kajian utama disebabkan pada masa itu pesantrenhanya mempelajari ilmu-ilmu keislaman saja, dan kitab-kitab klasik menjadi pilihan pang tepat serta akurat untuk dapat menggali keilmuan tentang Islam.
\end{abstract}

Kata Kunci: Kitab, Arab Klasik

\section{Pendahuluan}

Eksistensi pesantren sebagai lembaga pendidikan Islam tertua di Indonesia sangat membantu dalam mencetak kader-kader ulama yang handal dalam ilmu-ilmu agama. Untuk merealisasikan tujuan tersebut diselenggarakan pengajian kitab, yang di dalamnya terhimpun nilai-nilai dasar keislaman yang digunakan sebagai tata nilai dalam membentuk individu yang intelektual, berakhlak mulia, maka sejumlah kitab yang ditentukan untuk dipelajari di pesantren dipandang sebagai kurikulumnya.

Pemahaman kurikulum ini sejalan dengan pandangan Abidin Nata yaitu, "sejumlah mata pelajaran yang harus ditempuh untuk mencapai suatu ijazah atau gelar tertentu". ${ }^{1}$ Inti pokok dari pendirian pesantren adalah pusat pengkajian ilmu-ilmu keagamaan (Islam) seperti fiqh, ushul fiqh, tauhid, tafsir, hadits, tasawuf, akhlak, bahasa Arab, dan lain sebagainya. Ilmu-ilmu tersebut merupakan ilmu-ilmu agama Islam. Pengajaran ilmu-ilmu agama di pesantren pada umumnya dilaksanakan melalui pengajaran kitab-kitab klasik

\footnotetext{
${ }^{1}$ Abudin Nata, Filsafat Pendidikan Islam (Jakarta: Logos, 1997), hal.123
} 
(kitab kuning). ${ }^{2}$ Kitab-kitab bahasa Arab yang dipakai sebagai sumber belajar adalah kitab al-shafra' atau yang dikenal dengan kitab kuning. Kitab kuning merupakan materi pelajaran yang harus dipelajari di Pesantren. Makalah ini akan membahas secara global tentang pesantren dan kitab kuning.

\section{Pembahasan}

\section{Indigenousitas Pesantren}

Memahami kehidupan pesantren perlu ditelusuri watak-watak luhur yang berkembang dalam kehidupan pesantren. Ada tiga watak luhur (indigenousitas) pesantren, yaitu: keikhlasan, zuhud, dan kecintaan pada ilmu sebagai bentuk ibadah. ${ }^{3}$ Ketiga watak luhur Pesantren tersebut berangkat dari cara pandang pesantren terhadap kehidupan secara keseluruhan sebagai sarana ibadah. Cara pandang inilah yang menjadi kekuatan utama pesantren yang kemudian nampak dalam ketulusan, sikap zuhud dan kecintaan kepada ilmu-ilmu agama yang sangat tinggi serta mewarnai kehidupan pesantren.

Sejak seorang santri memasuki pesantren, ia mulai dikenalkan dengan dunia tersendiri, dimana peribadatannya menempati tempat tertinggi. Hal itu tampak dari jadwal dan disiplin ketat santri dalam menjalankan ibadah ritual seperti shalat berjamaah, dan ibadah ritual lainnya di lingkungan pesantren. Berangkat dari cara pandang terhadap kehidupan sebagai ibadah, maka para santri di pesantren dilatih untuk senantiasa tulus dan ikhlas dalam menjalankan semua aspek kehidupan. Upaya yang tidak pernah berhenti dan tiada mengenal lelah telah ditunjukkan oleh para Kyai, dari mulai merintis, mendirikan, hingga berkembang pesatnya sebuah pesantren tanpa mengharapkan imbalan duniawi sedikitpun, tidak akan bertahan lama, dan tidak akan bertahan lama jika tidak didasari dengan keikhlasan dan ketulusan yang luar biasa dalam diri seorang kyai. Upaya tersebut sekaligus merupakan teladan bagi para santri untuk senantiasa menjalankan semua yang diperintahkan kyai tanpa merasa keberatan sedikitpun, bahkan dengan penuh kerelaan seorang santri bersedia menghabiskan seluruh waktunya untuk berkhikmat kepada Kyai. Semua tidak akan bertahan bertahan jika tidak didasari dengan cara pandang yang menyeluruh terhadap kehidupan ini sebagai sebuah bentuk ibadah dan pengabdian kepada Allah swt yang telah tertanam dengan kuat dalam kepribadian mereka.

Nilai luhur yang menjadi watak dasariah pesantren juga tampak dari sikap zuhud dan kesahajaan pesantren. Di tengah hangar bingar kehidupan di luar pesantren yang serba mengedepankan materi, pesantren masih tetap bertahan dengan keserhanaan dan kesahajaan, sehingga dari sikap hidup yang bersahaja ini pesantren tetap kritis menyikapi perkembangan-perkembangan yang ada, termasuk arus modernisasi, dan sekarang arus globalisasi, meskipun pesantren terkadang dianggap tertutup dan resisten terhadap perkembangan-perkembangan tersebut. Hal itu tidak lain karena berangkat dari sudut pandang terhadap kehidupan, peribadatan mendapatkan perioritas tertinggi.

Berangkat dari cara pandang terhadap kehidupan sebagai sarana ibadah, pesantren memiliki cara pandang tersendiri terhadap ilmu pengetahuan. Bagi seorang santri, mencari ilmu adalah ibadah, sehingga waktu yang dihabiskan bertahun-tahun di pesantren tidak pernah dirasakannya sebagai sebuah kerugian. Karena mencari ilmu adalah ibadah, maka ilmu-ilmu agama di pesantren termasuk dalam katagori dalam wilayah sacral dan mendapat

\footnotetext{
${ }^{2}$ Haidar PutraDaulay, Historitas dan Eksistensi Pesantren, Sekolah, dan Madrasah (Yogyakarta: Tiara Wacana Kencana, 2001), hal. 26.

${ }^{3}$ Ibid., hal.188.
} 
posisi tersendiri dalam pandangan pesantren. Tidak sembarang orang dapat mengajarkan sebuiah ilmu tanpa ada ijazah dari guru yang dipercaya telah memiliki sandaran kuat pada guru-guru sebelumnya yang sandarannya sampai pada Rasulullah. Oleh karena itu di dinia pesantren yang mempertahankan tradisi ini, silsilah guru dan transmisi oral masih menjadi pertimbangan tersendiri.

Dari sudut pandang kehidupan sebagai ibadah dapat pula dimengerti bagaimana kecintaan pada ilmu-ilmu agama tertanam dengan kuat di pesantren. Dengan landasan inilah kemidian ilmu-ilmu agama memiliki supremasi tersendiri yang mutlak ditegakkan di pesantren, termasuk di dalamnya adalah system dan transmisi oral. Dengan demikian jalan ibadah yang sempurna adalah dengan menuntut ilmu secara terus menerus dan menyebarkannya kepada orang lain tanpa pamrih.

Dari sikap cinta kepada ilmu, kemudian dimanifestasikan dalam berbagai bentuk penghormatan seorang santri yang sangat dalam kepada ahli-ahli ilmu agama, kesediaan berkorban dan bekerja keras untuk menguasai ilmu tersebut dan kerelaan bekerja setelah ia menamatkan pendidikannya yang dituangkan dalam bentuk pendirian pondok pesantren atau mengajarkan ilmunya sebagai upaya penyebarluasan ilmu pengetahuan yang dimilikinya, karenanya, tidak salah jika dalam sejarah disebutkan bahwa pesantren memiliki kontribusi yang luar biasa, baik pada zaman penjajahan maupun pasca kemerdekaan, terutama dalam mewujudkan tujuan pendidikan dan pembangunan nasional yang pada gilirannya mweujudkan manusia yang beriman dan bertakwa kepada Allah swt, bahkan saat ini alumni pondok pesantren banyak yang berkiprah di instansi pemerintahan, ilmuan, dan sektor lainnya.

\section{Pengertian Kitab kuning (sistematika penjelasan definisi sebaiknya penje}

Kitab, merupakan istilah khusus yang digunakan untuk menyebutkan karya tulis di bidang keagamaan yang ditulis dengan huruf Arab. ${ }^{4}$ Sebutan ini membedakannya dengan bentuk tulisan lain pada umumnya yang menggunakan tulisan selain Arab dan disebut buku. Adapun kitab yang dijadikan sumber belajar di pesantren dan lembaga pendidikan tradisional, disebut kitab kuning. Dalam tradisi pesantren, kitab kuning merupakan ciri dan identitas yang tidak dapat dilepaskan. Sebagai lembaga kajian dan pengembangan ilmu-ilmu keislaman, pesantren menjadikan kitab kuning sebagai identitas yang inheren dengan pesantren. Bahkan Martin van Bruinessen menyatakan bahwa kehadiran pesantren hendaknya dapat mentransmisikan Islam tradisional sebagaimana terdapat dalam kitab-kitab kuning tersebut. ${ }^{5}$

Kitab kuning dapat disinonimkan dengan kitab klasik, tetapi lebih populer dengan sebutan kitab kuning. ${ }^{6}$ Dalam Ensiklopedi Hukum Islam diterangkan, bahwa kitab kuning adalah kitab yang berisikan ilmu-ilmu keislaman, khususnya ilmu fikih, yang ditulis atau dicetak dengan huruf Arab dalam bahasa Arab, melayu, Jawa dan sebagainya tanpa memakai harakat (tanda baris) sehingga disebut juga "kitab gundul".7 Abudin Nata

\footnotetext{
${ }^{4}$ Abudin Nata, Sejarah Pertumbuhan dan Perkembangan Lembaga-Lembaga Pendidikan Islam di Indonesia, (Jakarta: PT. Grafindo Widya Sarana Indonesia, 2002), hal.170

${ }^{5}$ Martin van Bruinessen, Kitab Kuning: Pesantren dan Tarekat (Bandung: Mizan, 1999), hal.17

${ }^{6}$ Haidar Putra Daulay, Sejarah Pertumbuhan dan Pembaharuan Penndidikan Islam di Indonesia (Yogyakarta: Cita Pustaka Media, 200), hal. 71

${ }^{7}$ Abdul Aziz Dahlan, Ensiklopedi Hukum Islam (Jakarta: PT. Ichtiar Baru Van Hoeve, 2002), hal.950
} 
menambahkan bahwa kita kuning merupakan hasil karya tulis Arab yang disusun oleh para sarjana muslim abad pertengahan, sekitar abad 16-18. ${ }^{8}$

Disebut kitab kuning karena pada umumnya kitab-kitab tersebut dicetak di atas kertas berwarna kuning, berkualitas rendah, dan kadang-kadang lembarannya lepas tidak terjilid sehingga mudah diambil bagian-bagian yang diperlukan tanpa harus membawa satu kitab secara utuh. Biasanya, para santri hanya membawa lembaran-lembaran tertentu yang akan dipelajari. Karena bentuk hurufnya yang gundul, kitab ini tidak mudah dibaca apalagi dipahami oleh yang tidak memahami gramatika bahasa Arab, nahwu dan sharaf.

Di daerah asalnya yaitu Timur Tengah, kitab kuning disebut dengan al-kutub almuqaddimah (buku klasik) sebagai saningan dari al-kutub. Al-`asriyyah. Kitab kuning yang beredar di Indonesia, khususnya di pesantren-pesantren jumlah dan jenisnya sangat terbatas. Diantara kitab klasik yang sangat dikenal adalah kitab-kitab yang berisi ilmuilmu syariat, khususnya ilmu fikih, tasawuf, tafisr, hadits,tauhid dan tarikh, sedangkan dari kelompok ilmu-ilmu non-syari at yang masyhur adalah kitab nahwu, sharaf (tata bahasa Arab) yang sangat dibutuhkan dalam memahami kitab klasik.

Ciri umum kitab kuning sebagai berikut: al-kitab yang ditulis bertulisan Arab, (2)umumnya ditulis tanpa baris, bahkan tanpa tanda baca dan koma, (3)berisika ilmu keislaman, (4)metode penulisannya dinilai kuno, (5)dicetak di atas kertas yang berwarna kuning, (6)lazimnya dipelajari di pondok pesantren. ${ }^{9}$

\section{Ragam Kitab Kuning}

Dilihat dari kandungan maknanya, kitab kuning dikelompokkan menjadi dua macam, yaitu:(1)Kitab kuning yang berbentuk penawaran atau penyajian ilmu secara polos seperti syarah, tafsir, hadist, dan sebagainya, 2) Kitab kuning yang menyajikan materi berbentuk kaedah-kaedah seperti ushull fiqh, mustalahul hadits.

Sedangkan dari segi kreativitas penulisannya, kitab kuning dapat dikatagorikan menjadi tujuh macam, yaitu:

a. Kitab kuning yang menampilkan gagasan baru yang belum pernah dikemukakan oleh penulis-penulis sebelumnya seperti kitab ar-Risalah (tentang ushul fiqh) karya Imam Syafi i, teori-teori ilmu kalam yang dimunculkan Washil bin `Ata, Abu Hasan al-Asy arid an sebagainya.

b. Kitab kuning yang muncul sebagai penyempurna terhadap karya yang telah ada, seperti kitab nahwu karya Sibawaihi (137-177 H), yang menyempurnakan karya Abu al-Aswad Zalim bin Sufyan ad-duwali (wafat 69/688M)

c. Kitab kuning yang berisi komentar atau syarah terhadap kitab yang telah ada, seperti kitab Fathu al-Bari fi Syarah Shahih al-Bukhari karya Ibnu Hajar alAsqalani yang memberi komentar terhadap Sahih al-Bukhari.

d. Kitab kuning yang meringkas karya yang panjang lebar untuk dijadikan karangan singkat tetapi padat, seperti al-Fiyah bin Malik (tentang nahwu) karya Ibnu `Aqil.

e. Kitab kuning yang berupa kutipan dari berbagai kitab lain seperti Ulum alQur`an.

f. Kitab kuning yang isinya memperbaharui sistematika dari kitab-kitab yang telah ada seperti Ihya Ulum al-Din karya Imam Gazali.

\footnotetext{
${ }^{8}$ Abudin Nata, Sejarah Pertumbuhan dan Perkembangan..., hal.170 .

${ }^{9}$ Haedar Putra Daulay, Sejarah Pertumbuhan dan Pembaharuan ..., hal. 150
} 
g. Kitab kuning yang berisi kritik dan koreksi terhadap kitab-kitab yang telah ada, seperti Mi yar al-Ilmi (buku yang meluruskan kaedah logika yang telah ada) karya Imam Gazali. ${ }^{10}$

Dilihat dari kadar penyajiannya, kitab kuning dibagi pada tiga macam, yaitu: a) Kitab matan, b) Kitab Syarah, c) Kitab hasyiyah (komentar atas kitab komentar). ${ }^{11}$ Tiga jenis kitab ini juga menunjukkan tingkat kedalaman dan kesulitan tertentu.

Dalam Suplemen ensiklopedi Islam, kitab kuning jika dilihat dari kadar penyajiannya dapat dibagi menjadi 3 macam : (1)Mukhtasar, yaitu kitab yang tersusun secara ringkas dan menyajikan pokok-pokok masalah, baik yang muncul dalam bentuk nazam atau syi $r$ (puisi) maupun dalam bentuk nasr (prosa), (2)syarah, yaitu kitab kuning yang memberikan uraian panjang lebar, menyajikan argumentasi ilmiah secara komparatif, dan banyak mengutip alasan para ulama dengan argumentasi masing-masing, (3)kitab kuning yang penyajian materinya tidak terlalu panjang (mutawassitoh $)^{12}$

\section{Kitab Kuning Sebagai Sumber Belajar}

Sejak awal mula berdirinya pesantren, tradisi membaca, mempelajari kitab klasik menjadi hal yang penting, bahkan menjadi sesuatu yang inheren di pesantren. Keberadaan kitab kuning ini menjadi kajian utama disebabkan pada masa itu pesantrenhanya mempelajari ilmu-ilmu keislaman saja, dan kitab-kitab klasik menjadi pilihan pang tepat serta akurat untuk dapat menggali keilmuan tentang Islam. ${ }^{13}$

Yang penulis kemukakan diatas merupakan uraian eksistensi pengkajian kitab kuning pada pondok pesantren yang tergolong tradisional atau salafiah. Pada pesantren salafiah, pengajian kitab kuning meruakan mutlak dilaksanakan. Sampai saat ini pesantren yang tergolong salafiah tetap mengkaji kitab kuning. ${ }^{14}$

Kitab-kitab klasik (kitab kuning) yang diajarkan di pesantren dapat digolongkan pada delapan kelompok: nahwu/ syaraf, fikh, ushul fiqh, hadits, tauhid, tasawuf dan etika, serta cabang-cabang ilmu lainnya seperti tarikh dan balaghah. ${ }^{15}$

Berbeda dengan pesantren yang bercorak modern, maka pengkajian kitab kuning tidak mengambil bagian yang penting, bahkan tidak diajarkan lagi. Pengkaian ilmu-ilmu agamanya diambil dari kitab-kitab yang disusun oleh ulama-ulama yang tergolong mutaakhir, misalnya pondok pesantren modern Darussalam Gontor Ponorogo ${ }^{16}$

Di Pesantren, kitab kuning dianggap formulasi final dari ajaran-ajaran al-Qur`an dan sunnah Nabi. Kitab yang ditulis para ulama dengan kualitas ganda yaitu keilmuan yang tinggi dan moralitas yang luhur. Kitab ini juga ditulis dengan mata pena atau jari-jari yang bercahaya, akibatnya dipandang hampir sempurna dan sulit mengkritiknya. ${ }^{17}$

${ }^{10}$ Abdul Aziz Dahlan, Ensiklopedi Hukum Islam, (Jakarta: PT. Ichtiar Baru Van Hoeve, 2002), hal.

952

${ }^{11}$ Mujamil Qomar, Pesantren dari Transformasi Metodologi Menuju Demokratisasi Instansi (Jakarta: Erlangga, 2005), hal. 127

${ }^{12}$ Departemen Pendidikan Nasional, Suplemen Ensiklopedi Islam (Jakarta: PT. Ictiar Baru Van Hoeve, 2002), hal.335.

${ }^{13}$ Haeidar, Sejarah Pertumbuhan dan Pembaharuan ..., hal. 150

${ }^{14}$ Ibid., hal. 19

${ }^{15}$ Ibid., hal. 18.

${ }^{16}$ Ibid., hal. 19

${ }^{17}$ Aya Sofia, Pedoman Penyelenggaraan Pusat Informasi Pesantren, (Jakarta: Depag, 1985),

hal.41

Al-Ikhtibar: Jurnal Ilmu Pendidikan Volume 6 No. 2, Desember 2019 
Implikasi selanjutnya adalah, kitab kuning dianggap suci atau sakral yang mengandung kebenaran sejati, sehingga tidak perlu lagi direformulasi. Ketika terjadi pensakralan terhadap kitab ini, maka potensi santri akan stagnan dan tidak mau mencoba membuktikan kreativitas dirinya. Oleh karena itu dalam menyikapi keberadaan kitab ini, para peminat studi keislaman menunjukkan tiga sikap, yaitu:

1. Sikap menolak secara apriori terhadap semua kitab kuning dengan alas an bahwa pemikiran ulama yang tertuangg dalam kitab tersebut sudah tidak relevan dengan kebutuhan dan tuntutan zaman modern.

2. Sikap menerima sepenuhnya dengan alasan bahwa pendapat ulama yang terdapat di dalamnya sudah dianggap baku dan telah disepakati secara ijma` oleh kaum muslimin. Sikap ini tampak terutama pada pendukung mazhab fiqh tertentu terhadap kitab kuning dlam bidang fiqh mazhabnya.

3. Sikap menerima secara kritis, yaitu menerima pendapat ulama yang tertuang dalam kitab-kitab tersebut setelah terlebih dahulu meneliti kebenarannyaserta mengembangkannya lebih lanjut.

Walaupun kitab kuning ini dipakai oleh pesantren- pesantren salafi ataupun pesantren modern sebagai sumber belajar, namun Azyumadi Azra mengatakan sampai saat ini belum ada seorang ahli sejarahpun yang mengetahui persis mulai terjadinya penyebaran dan pembentukan awal tradisi kitab kuning di Indonesia. ${ }^{18}$

\section{Metode Pembelajaran Kitab kuning}

Terdapat beberapaunsur penting yang harus diperhatikan dalam mengikuti proses pembelajaran kitab-kitab di pesantren-pesantren yang berubungan dengan interaksi antara guru dan murid dan sumber belajar, diantaranya adalah:

a. Kyai sebagai guru yang harus dipatuhi secara mutlak dan dihormati yang kadangkadang dianggap memiliki kekuatan gaib, yang dapat memberi berkah.

b. Untuk memperoleh ilmu, tidak cukup dengan rasio saja, metode yang benar dalam mencarinya, dan kesungguhan berusaha, tetapi sangat bertantung dengan kesucian jiwa, serta upaya-upaya ritual keagamaan seperti puasa, do`a maupun rangkaian ibadah lainnya.

c. Menghargai dan menghormati kitab-kitab atas jasanya yang telah banyak mengajar santri.

d. Transmisi lisan para kyai sangat penting walaupun santri mampu menelaah kitabnya sendiri. ${ }^{19}$

Pengajaran kitab kuning mempergunakan berbagai metode, diantaranya, 1)metode hafalan, 2) sorogan, 3)wetonan, 4) muzakarah, 5) majlis. ${ }^{20}$

\section{Urgensi Pembelajaran Kitab Kuning dalam Pemikiran Keagamaan}

\footnotetext{
${ }^{18}$ Azyumardi Azra, Pendidikan Islam: Tradisi dan Modernisasi Menuju Millenium Baru, (Jakarta : Logos, 1999), hal.111

${ }^{19}$ Mastuhu, Prinsip Pendidikan Pesantren, (Jakararta: P3M, 1988), hal. 285-286

${ }^{20}$ Abudin Nata, Sejarah Pertumbuhan dan Perkembangan..., hal.176
} 
Kitab kuning mengkaji tentang ilmu-ilmu keislaman, tentu menjadi hal yang penting dalam paradigma pendidikan Islam. Dengan mempelajari ilmu-ilmu keislaman dari kitab klasik atau kitab kuning, maka santri akan mendapatkan pemahaman keilmuan Islam yang baik.

Kitab kuning menjadi materi yang penting di Pesantren, terutama di kalangan pesantren tradisional atau salafiah. Oleh karena itu, pesantren selalu mengadakan pengajian kitab kuning yang biasanya pesantren membuat jadwal secara lengkap tentang waktu, tempat kiyai yang mengajar, serta nama kitab yang dibaca.

Dengan fenomena tersebut, maka santri akan mempunyai bekal yang baik akan ilmu-ilmu keislaman.

Kriteria kemampuan membaca dan mensyarahkan kitab bukan saja merupakan kriteria diterima atau tidaknya seorang kiay sebagai ulama pada zaman dahulu, tetapi sampai sekarang. Syarat seorang kiay atau ulama telah memenuhi kriteria sebagai kiay atau ulama adalah kemampuannya membaca serta menjelaskan isi kitab-kitab tersebut. ${ }^{21}$

Mempelajari kitab kuning merupakan suatu hal yang urgent, sebab kitab kuning merupakan sumber ilmu-ilmu keislamalan, dan untuk dapat menjadi ilmuan, kiyai yang mumpuni tentu harus dapat menguasainya.

\section{B. Kesimpulan}

Pesantren merupakan lembaga pendidikan Islam tertua di Indonesia yang memiliki peran serta dalam membangun generasi yang tangguh dalam hal agama, moral dan kemampuan intelektual. Untuk merealisasikan tujuan tersebut, pesantren membekali santrinya dengan berbagai ilmu pengetahuan, diantaranya dengan memakai ikitab kuning sebagai sumber belajar. Kitab kuning merupakan satuan pelajaran yang harus diikuti dan dikuasai santri yang belajar di pesantren salafi ataupun modern. Menguasai kitab kuning merupakan hal yang urgen bagi santri, sebab dalam kitab tersebut terdapat sumber-sumber keilmuan tentang agama Islam, untuk itu santri harus dapat menguasai alat bantu seperti nahwu dan sharaf agar mudah memahami isi kitab kuning. Kitab kuning sudah ada sejak abad pertengahan, namun tetap eksis sampai sekarang sebagai rujukan dalam ilmu-ilmu keagamaan.

\section{Daftar Pustaka}

Abdul Aziz Dahlan, Ensiklopedi Hukum Islam (Jakarta: PT. Ichtiar Baru Van Hoeve, 2002)

Azyumardi Azra, Pendidikan Islam: Tradisi dan Modernisasi Menuju Millenium Baru (Jakarta : Logos, 1999)

Abudin Nata, Filsafat Pendidikan Islam (Jakarta: Logos, 1997) , Sejarah Pertumbuhan dan Perkembangan Lembaga-Lembaga Pendidikan Islam di Indonesia (Jakarta: PT. Grafindo Widya Sarana Indonesia, 2002)

\footnotetext{
${ }^{21}$ Haidar Putra Daulay, Sejarah Pertumbuhan dan Pembaharuan ..., hal. 18.
} 
Amin Haedari, Masa Depan Pesantren dalam Tantangan Modernitas dan Tantangan Kompesitas Global (Jakarta: IRD Press, 2005)

Aya Sofia, Pedoman Penyelenggaraan Pust Informasi Pesantren, (Jakarta: Depag, 1985)

Departemen Pendidikan Nasional, Suplemen Ensiklopedi Islam (Jakarta: PT. Ictiar Baru Van Hoeve, 2002)

Haidar PutraDaulay, Historitas dan Eksistensi Pesantren, Sekolah, dan Madrasah (Yogyakarta: Tiara Wacana Kencana, 2001)

Haidar Putra Daulay, Sejarah Pertumbuhan dan Pembaharuan Penndidikan Islam di Indonesia (Yogyakarta: Cita Pustaka Media, 200)

Martin van Bruinessen, Kitab Kuning: Pesantren dan Tarekat (Bandung: Mizan, 1999)

Mujamil Qomar, Pesantren dari Transformasi Metodologi Menuju Demikratisasi Instansi (Jakarta: Erlangga, 2005)

Mastuhu, Prinsip Pendidikan Pesantren (Jakararta: P3M, 1988) 